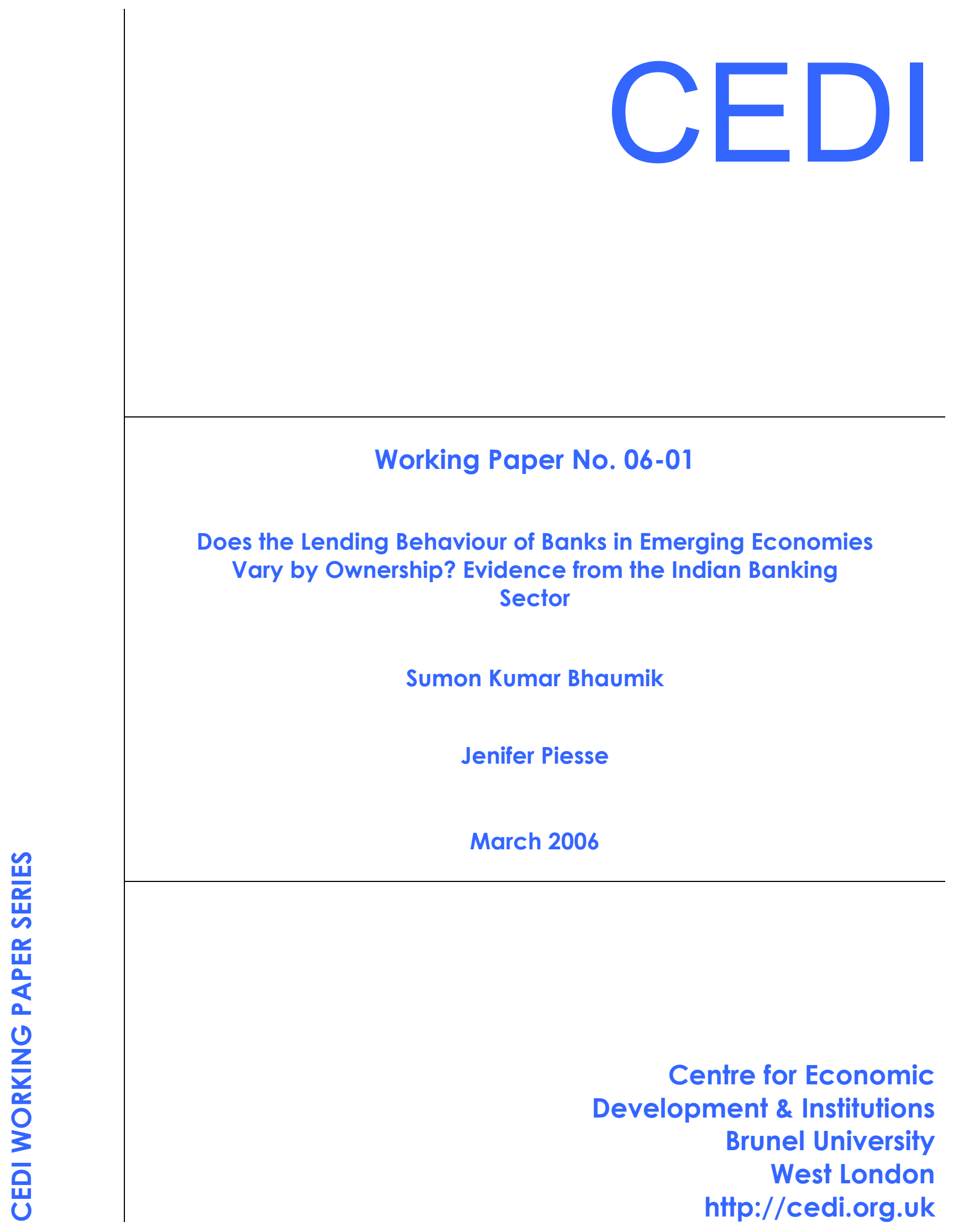




\title{
Does lending behaviour of banks in emerging economies vary by ownership? Evidence from the Indian banking sector*
}

\author{
Sumon Kumar Bhaumik** \\ Centre for Economic Development and Institutions \\ Brunel University \\ Jenifer Piesse \\ King's College London, and \\ University of Stellenbosch, RSA
}

\begin{abstract}
:
While much has been discussed about the relationship between ownership and financial performance of banks in emerging markets, literature about cross-ownership differences in credit market behaviour of banks in emerging economies is sparse. Using bank-level data from India, and a portfolio-choice model, for nine years (1995-96 to 2003-04), we examine banks' behaviour in the context of emerging credit markets. Our results indicate that, in India, the data for the domestic banks fit well the aforementioned portfolio-choice model, especially for private banks, but the model cannot explain the behaviour of foreign banks. In general, allocation of assets between risk-free government securities and risky credit is affected by past allocation patterns, stock exchange listing (for private banks), risk averseness of banks, regulations regarding treatment of NPA, and ability of banks to recover doubtful credit. It is also evident that banks deal with changing levels of systematic risk by altering the ratio of securitized to nonsecuritized credit. These results have implications for disbursal of credit to small and medium enterprises in India.
\end{abstract}

JEL classification: G21, O16

Keywords: India, Banking sector reforms, Credit disbursal, Risk appetite, Ownership

March 20, 2006

\footnotetext{
* The authors would like to thank Allen Berger, Anthony Saunders, Jan Krahnen, Steven Ongena, Sujata Visaria, Viral Acharya, Rudra Sensarma and seminar participants King's College London, Brunel University, and at the "Bank relationships, credit extensions, and the macrcoeconomy" conference organised by DIW, Berlin for their comments on earlier versions of the paper. They are grateful to Christopher Baum for his advise about the econometric methodology used in the paper. The authors remain responsible for all remaining errors.

"Corresponding author. Address: Brunel University, Centre for Economic Development and Institutions, Brunel Business School, Social Sciences Building, Uxbridge UB8 3PH, Middlesex, UK. Phone: +44 1895 267247. Fax: +44 1895 269786. Email: Sumon.Bhaumik@brunel.ac.uk.
} 


\section{Does lending behaviour of banks in emerging economies vary by ownership? Evidence from the Indian banking sector}

\section{Background}

Much of the literature on banking in emerging markets focuses on either the broad relationship between ownership and financial performance (e.g., Sarkar, Sarkar and Bhaumik, 1998) or the agency aspect of ownership, i.e., the impact of separation between management and ownership on the performance of banks (e.g., Gorton and Schmid, 1999; Hirshey, 1999). The focus on the relationship between ownership and financial performance of banks in emerging markets stems from concern about both the possibility of inefficient allocation of scarce financial resources in the presence of dominant public sector banks that often manifest McKinnon-Shaw type financial repression, and also from the concern about the possible fiscal impact of banking sector fragility in an environment where directed credit, political patronage, and severe moral hazard on the part of public sector bank officials can lead to significant accumulation of nonperforming assets (NPAs).

While the focus on the relationship between ownership and financial performance is not completely unjustified in the context of banks in emerging markets, it has drawn attention away from the fact that, unlike a manufacturing or services sector firm, a bank helps mobilize domestic savings for subsequent investment in various on-going and new projects, and thereby is also the conduit for the transmission of monetary policy, and the facilitator of economic growth. Indeed, it is now stylized in the literature that the intermediary role of banks plays an important role in encouraging growth, even though in some countries a well-functioning credit market has added the unwelcome effect of increasing debt accumulation rather than improving total factor productivity (Gertler and Gilchrist, 1993; Ketkar, 1993; Ma and Smith, 1996; Bulir, 1998; Acemoglu, 2001; Bell and Rousseau, 2001; Da Rin and Hellman, 2002; Jeong, Kymn and Kymn, 2003). Thus, not only are allocative efficiency and financial performance of banks important, but so also is the amount of credit disbursed by these financial intermediaries, especially when bank financing 
is the main source of finance in most countries (Mayer, 1990).

The relatively small literature on the relationship between ownership and credit disbursal by banks address two different issues. In the context of developed market economies (e.g., Italy), the evidence suggests that state-owned banks charge lower rates of interests on the loans than private banks, and are more likely to lend to larger firms and those based in economically depressed areas (Sapienza, 2004). In other words, state-owned banks have a mandate to pursue social justice, aside from efficient allocation of credit. These banks may also be influenced by political processes: using Indian data, Banerjee and Duflo (2002) show that public sector or state-owned banks can exhibit risk averseness, on account of the political economy of blame sharing in the event of poor bank performance. Evidence from middle-income countries from Latin America (e.g., Argentina) suggests that foreign banks are especially risk averse and that significant market penetration by these banks in a developing economy context might adversely affect credit disbursal to small and medium enterprises (Clarke, Cull, D'Amato and Molinari, 1999; Clarke, Cull, and Peria 2001; Clarke, Cull, Peria and Sanchez, 2002). Mian (2006) has argued that this reluctance stems from the inability of foreign banks to recover loans by way of bilateral negotiations with local borrowers, and hence the extent of this reluctance increases with the cultural distance between the country of origin of a foreign bank and the country in which it operates. However, there is nothing to suggest that private ownership (or privatization) of bank would have a similar effect (Clarke, Crivelli and Cull, 2005).

However, there is no empirical evidence about the comparative behaviour of banks of different ownership in emerging credit markets, even though there is reason to believe that the credit disbursal behaviour in rapidly reforming emerging markets may vary significantly across banks of different ownership types, albeit not necessarily in any predictable manner. Specifically, given the relatively high levels of systematic risk and information failures in such markets, state-owned banks may either adopt a role to minimize the extent of market failure, or may respond to political pressures (a la Banerjee and Duflo) by lending only to firms with which they have long established relationships, even if these firms are not fast- 
growing and innovative. Berger et al. (2005), for example, argue that state-owned banks, private banks and foreign banks in India have a comparative advantage in forging main-bank relationships with stateowned firms, closely held private ("opaque") and foreign firms, respectively. Similarly, private sector banks may respond to financial liberalization either by lending very cautiously in the face of profiteroding capital and NPA provisioning requirements, or may embark upon rapid expansion of credit to capture a larger share of the market. Finally, foreign banks may use new branching and other opportunities to rapidly expand credit, or may remain content by "cherry picking" the low risk borrowers in the credit market while focusing on expansion of non-interest income by way of fee-based services.

We address this lacuna in the literature by examining the differences in the credit disbursal behaviour of Indian banks of different ownership types. The choice of India as the backdrop for the empirical study is well justified. The Indian banking sector has a multiple ownership structure, comprising public sector banks, incumbent and de novo private domestic sector banks, and foreign banks. In addition, significant reforms and liberalization has taken place since the early 1990s (Sarkar, Sarkar and Bhaumik, 1998, Shirai and Rajsekaran, 2001; Bhaumik and Mukherjee, 2002), thereby granting all banks effective operational autonomy. Recent literature has found evidence of convergence among these different types of Indian banks in terms of financial performance (Bhaumik and Dimova, 2004), indicating that they have taken advantage of the reforms to compete with each other, and learn from each other sufficiently to be able to invade each other's market niches. However, the existing literature does not indicate whether there has also been a convergence in the behaviour of the different types of banks with respect to credit disbursal. At the same time, despite a large market capitalization by developing country standards, banks remain the main source of capital for most micro, small and medium enterprises. Hence, Indian banking provides an ideal setting for further analysis.

By and large, banks in India have the choice of allocating resources to safe government bonds, or risky private borrowers, and this choice is manifested in the credit-to-deposit ratio (CDR). In this paper, we 
motivate and estimate a model that expresses CDR as a function of the credit risk associated with the banks' potential borrower pool, and the risk averseness of the banks. Our econometric specification also controls for persistence in credit market behaviour as captured by past credit-to-deposit ratio, demand for credit using GDP growth rate as proxy, and a major regulatory change during the period under consideration. The resultant dynamic model is estimated using data from the Indian banking sector for 1995-96 through 2003-04, and the methodology proposed by Blundell and Bond (1998).

Our analysis confirms that there are significant differences in the behaviour of public and private sector banks in the Indian context. There is a strong persistence in the credit-to-deposit ratios of both types of banks. However, while credit disbursal by the former can be explained largely by the impact of regulatory changes and (weakly) by the stock of NPA on their balance sheets, credit disbursal by the latter is also explained by the extent of their branch networks and the extent of their risk averseness. Our results are robust to the choice of the measure of credit, and are consistent with the existing literature documenting micro evidence from individual banks. The main policy implication of our results is that the Indian government might have to focus on strengthening the institutional structure associated with delivery of micro-credit to small and medium enterprises (SMEs) that are typically more dependent on bank credit than larger organisations. Indian commercial banks that have to abide by prudential regulatory norms might hesitate to disburse credit to firms that inherently carry higher credit risk, and those that do not have the ability to reduce the liquidity risk of the banks by borrowing through the market for securitised credit. Access to bank credit may be even more difficult for start-up firms that do not have long standing relationship with banks. The survival and growth of SMEs may, therefore, be at risk.

The rest of the paper is organized as follows. The Indian banking sector reforms, especially those related to credit disbursal by banks, are outlined in Section 2. Section 3 develops the theoretical basis for the model used and states the model specifications. The data are discussed in Section 4 and the result in Section 5. Section 6 concludes. 


\section{The context: Banking reforms in India}

Independent India inherited a weak financial system. Commercial banks mobilized household savings through demand and term deposits, and disbursed the credit primarily to large corporations (Ghosh, 1988). This lop-sided pattern of credit disbursal, and perhaps a spate of bank failures that reduced the number of banks from 566 in 1951 to 90 in 1968, led the government to nationalize the banks in 1969. The main thrust of nationalization was social banking, with the stated objective of increasing the geographical coverage of the banking system, and extension of credit to the priority sector that comprised largely of agriculture, agro-processing, and small-scale industries. This phase of banking in India was characterized by administered interest rates, mandatory syndicated lending, and pre-emption of the banks' deposit base by the government in the form of measures like the statutory liquidity ratio (SLR). Banks were required to invest a significant proportion of their deposits in bonds issued by the government and "approved" (quasigovernment) institutions. At the same time, between 1969 and 1990, the nationalized banks added over 55,000 branches to their network (Sarkar and Agarwal, 1997).

While the social agenda of the banking sector, measured in terms of geographical and sectoral coverage, was arguably a success, the Indian banking sector, about 88 percent of whose assets were managed by state-owned banks, was in distress. While the ratio of gross operating profit of the scheduled commercial banks rose from 0.8 percent (of assets) in the seventies to 1.5 percent in the early nineties, the net profit of the banks declined. More importantly, perhaps, financial repression involving state-owned banks was not in harmony with the agenda of real sector reforms that the government of India unleashed in the aftermath of the balance of payments crisis of 1991. The Reserve Bank of India (RBI), therefore, initiated reform of the banking sector in 1992, based on the recommendations of Narasimham Committee I (see Reddy, 1998).

Between 1992 and 1997, the cash reserve ratio (CRR) was reduces from 15 percent to about 10 percent, 
and the SLR was reduced from 38.5 percent to 25 percent over the same period. The interest rates were gradually liberalized: Prior to 1992, the lending rates structure consisted of six categories based on the size of advances. During the 1992-94 period, the lending rates structure was rationalised to three categories, and in 1994 banks were given the freedom to determine interest rates on all loans exceeding Indian rupees (INR) 200,000 (i.e., USD 4,500). By 1998, banks were free to determine the interest rates for all loans, with the understanding that the lending rates on loans up to INR 200,000 would not exceed the declared prime lending rates (PLR) of the banks.

Prior to the initiation of reforms, banks were required to refer all loans above a size threshold to the RBI for authorization, and formation of a consortium was mandatory for all loans exceeding INR 50 million. Bank credit was delivered primarily in the form of cash credit for use as working capital, and there were significant restrictions on the ability of banks to deliver term credit for projects. Finally, the RBI implemented selective credit controls on "sensitive" commodities.

In the wake of the reforms, as early as in 1993, the threshold for the mandatory formation of consortiums was raised from INR 50 million to INR 500 million. Further, banks within consortiums were permitted to frame the rules or contractual agreements governing the consortium lending. In 1996, selective credit controls on all sensitive commodities except sugar were removed. Banks were also allowed much greater flexibility about the proportion of the cash credit component of the loans, the new floor being 25 percent. The following year witnessed further elimination of credit controls: Banks were no longer subjected to the instructions pertaining to Maximum Permissible Bank Finance (MPBF), and were allowed to evolve their own methods for assessing the credit needs of the potential borrowers. Further, banks were no longer required to form consortiums to lend in excess of INR 500 million, and restrictions on their ability to provide term loan for projects were withdrawn. However, prudential regulations required that an individual bank not be over-exposed to any one (or group of) creditor(s). 
Finally, in 1998, the RBI initiated the second generation of banking reforms, in keeping with the recommendations of Narasimham Committee II. The most important recommendation of the Committee was the creation of asset reconstruction companies (ARCs) to simultaneously improve the quality of the balance sheets of the banks and to facilitate recovery of loans. In a separate development, after a prolonged period of legal disputes, debt recovery tribunals (DRTs) began functioning in India, in earnest, by 1999.

In other words, the post-1991 reforms period affected the Indian banks in two different ways: they had more freedom to take credit related decisions, and, at the same time, were reined in by prudential regulations that penalized accumulation of NPA on their balance sheets. The impact of prudential norms, specifically, capital requirements, on credit disbursal has been examined in the banking literature (e.g., Berger and Udell, 1994; Thakor, 1996; Ashcraft, 2001; Furfine, 2001; Godlewski, 2004). However, the contexts of these studies were not emerging market contexts where the introduction of potentially restrictive prudential norms, in general, coincided with greater freedom to allocate credit and determine portfolio composition. To recapitulate, by 1996, banks operating in India, were, by and large, in a position to take independent decisions on the composition of their asset portfolio, and on the choice of potential borrowers. Furthermore, there is evidence to suggest that these banks, including the state-owned ones,

allocated resources in a way that was consistent with maximization of returns. ${ }^{1}$ Hence, the Indian banking sector was an ideal emerging market context in which banks were able to allocate resources across assets of various risk-return profiles, while, at the same time, facing significantly high levels of systematic risk that characterizes emerging markets.

We model the behaviour of a representative Indian bank in the following section.

\section{Modelling bank behaviour in credit markets}

A bank is a multi-product firm, with a portfolio consisting of non-securitized loans, as well as securities 
issued by non-government entities and federal, state and local governments. In addition, a bank generates revenues from fee-based contracts and speculation/participation in the market for off-balance sheet items. In developing countries, the choices facing the banks are usually fairly limited, partly because of government regulations, but also because of missing or underdeveloped markets for assets and instruments such as equity and financial derivatives. For example, in India, equities accounted for less that 1 percent of the bank assets through the early years of the current century. At the same time, while states, regions and local bodies in developing countries have different degrees of credit worthiness, the political economy of most of these countries ensure that all government securities carry the implicit or explicit guarantee by the federal government. It is, therefore, possible to think of banks in developing countries having two broad choices: they can either invest their resources, net of the cash reserve ratio and other regulatory caveats, into safe government securities, or disburse them as credit to the non-government sector, when all such credit inherently carries credit risk.

Let the following be true: the return on the risk-free government bonds is $r_{f}$, the expected return on the risky credit-related assets is $E\left(r_{p}\right)$, and a bank invests $y$ proportion of its resources in the latter and $(1-y)$ proportion in the former. Then, the expected returns arising out of this asset allocation is given by

$$
E(r)=r_{f}+y\left[E\left(r_{P}\right)-r_{f}\right]
$$

Now let the utility function of the bank be given by

$$
U=E(r)-A \sigma^{2}
$$

where $\sigma$ is the risk associated with the asset allocation strategy, and $A$ is the extent of risk averseness of the bank. The optimization program of the bank is then by $\operatorname{Max}_{y} U$ resulting in $y^{*}$ as a function of $E\left(r_{p}\right), r_{f}$, $\sigma$ and $A$.

If an empirical analysis is limited to a single country, with limited capital account convertibility, then, for any year, $r_{f}$ (i.e., some average of the returns on government securities of different maturities) is similar 
across all banks. Hence, cross-sectional variation in $y^{*}$ (i.e., CDR) across banks can be explained by variations in the returns on the non-government assets, the risks associated with these assets, and the degrees of risk aversion of the individual banks. The CDR of a bank would be expected to increase with the expected return on the non-government assets, and decrease with the risk associated with such assets and also the degree of risk averseness. The overall risk associated with a bank's portfolio of nongovernment assets would, in turn, be inversely related to the average quality of the pool of potential borrowers, and the ability of the bank to diversify its portfolio across a wide range of borrowers. A bank's degree of risk averseness, on the other hand, would depend on factors like its faith on internal credit scoring systems and its ability to withstand political scrutiny, and would be manifested by its resource allocation between safe and risky assets. Finally, regulations involving, for example, mandatory lending to high risk groups on account on socio-political compulsions of the government, and adherence to the Basle principles would affect both the risk associated with non-sovereign assets.

Asset pricing theory suggests that risk and return are positively related. ${ }^{2}$ Alternatively, since a bank loan is similar to a coupon bond held until maturity, the risk associated with a bank loan is a credit risk, not an interest rate risk, and it can be argued that the expected returns from bank loan is simply a linear function of the credit risk. In other words, the inclusion of both a measure of risk and expected returns in the specification is likely to give rise to collinearity. Therefore, the specification can be further reduced to a functional relationship between the CDR and both the credit risk associated with loan disbursals and the risk averseness of the banks.

Given that banking is a relationship-based activity, the borrower pool for any bank is usually restricted by the geographical coverage of its branch network, and its regions of operation. In this study, geographical coverage of a bank is measured by the size of its branch network. ${ }^{3}$ Further, it is important to consider that the policy legacies of Indian banks that led to large rural networks (see Bhaumik and Mukherjee, 2002), and treat Indian as being comprised of broadly two large regions, rural and urban. This is taken into 
account by using the proportion of the branch network that is in rural areas. Since a large branch network enables a bank to minimize the risk associated with its portfolio by diversification across a large number of borrowers, it is expected that the CDR increases with the size of the branch network (BRANCHES). On the other hand, credit disbursal in the rural market is likely to be more risky than credit disbursal in the urban market. The higher risk associated with rural markets in emerging markets like India can be explained by inability of many (or most) of the borrowers to post adequate collateral, missing secondary markets for collateral, higher transactions costs associated with contract enforcement in areas that are not well connected to urban centers, and the political economy of loan forgiveness. Thus, it is expected that CDR is inversely related to the proportion of branches in the rural areas (RURALPROP).

The risk averseness of a bank can arise from two different sources. Firstly, a bank may be innately risk averse, but may also be reluctant to take risk on account of factors such as, the impact of past behaviour with respect to credit decisions. In India, the degree of innate risk averseness bank is not difficult to measure, and initially, it can be argued that banks with different ownership patterns (OWNERSHIP) have different levels of innate risk averseness. In our analysis, we control for this source of risk averseness by separately estimating the credit function for public and private sector banks.

The second measure of innate risk averseness in banks is likely to have a predictable relationship with the choice of CDR. All banks in India are required by the Reserve Bank of India (RBI) to maintain a proportion of their deposits - the SLR - in the form of safe and liquid assets, mostly in the form of government securities. However, since the mid nineties, most banks have voluntarily invested much more than the required minimum proportion of their assets in government securities, behaviour that in Indian policy circles is known as "lazy banking." The rationale for lazy banking is the risk associated with credit disbursal in a developing country with attendant economic cycles and underdeveloped legal institutions to enforce contracts, and also awareness of the responsible banks that they may not have the necessary expertise to screen potential borrowers. Thus, lazy banking is a manifestation of risk averseness. We use 
the difference (or "distance") between a bank's actual exposure to government securities, as a percentage of deposits and the required minimum proportion as a measure of risk averseness (ExGOV securities). ${ }^{4}$ Clearly, a high value for this variable would indicate a high degree of risk averseness. In order to avoid endogeneity problems, the risk aversion measure is lagged one period.

Legacy may also have an impact on the risk averseness of a bank in two different ways. Given that the Indian banks are expected to abide by the prudential norms laid down by the RBI, if past lending of a bank results in accumulation of non-performing assets, it imposes a cost on the bank in the form of both higher capital requirements and higher cost of capital. This cost of capital might then cause a bank to restrict its lending activities so as to reduce further the capital requirement. Conversely, a bank with a large stock of bad or doubtful assets may wish to expand operations rapidly to make up for past losses and/or to become too big to fail (see, e.g., Randall, 1993). Hence, in this study, past evidence of NPA is used as a measure of regulation and/or legacy induced risk averseness (NPA).

The RBI also requires banks to reserve a stipulated minimum share of disbursed credit for the priority sector, which is comprised largely of agriculture and small firms. Banerjee, Cole and Duflo (2003) have noted that the average risk associated with priority sector lending is high, thereby giving banks an incentive to not fulfil their priority sector obligations, if possible. Cognizant of this agency problem, the RBI imposes a statutory penalty on banks that fail to meet their priority sector obligations; a "defaulting" bank is required to invest the difference between its required and actual exposures to the priority sector in government bonds yielding below-market rates of return. Despite the penalty, however, data suggest that in any given year some banks are unable to meet the RBI regulation on priority sector lending. This raises the possibility that either the penalty is not well enforced or that the penalty is not commensurate with the gains accruing to a bank that does not expose itself significantly to the risky priority sector. In other words, if a bank does not meet the minimum required exposure to the priority sector in year $t-1$, there are two possible outcomes in year $t$. The bank can either decide that the RBI's priority sector lending norms 
are not well enforced, or it braces for a RBI-imposed penalty and hence compensates for its errant past by increasing its exposure to priority sector lending. In the former case, the risk averseness of the bank in period $t$ is likely to decline while, in the latter case, its risk averseness in that period is likely to increase. As with investment in government securities, a proxy for this risk aspect of aversion is a bank's "distance" from the RBI mandated lower limit for priority sector exposure (PRIORITY). Risk averseness would increase or decrease with this measure depending upon the effectiveness with which the RBI enforces priority sector lending requirements. As above, possible endogeneity is avoided by using a lagged value in the estimation.

Further, as discussed earlier, it may be important to take account of the possibility of persistence, that is, whether CDR in time period $t$ is significantly dependent on the CDR in time period $t-1$. This outcome may be due to the relationship-based nature of banking, or is evidence of the inability of banks to assess credit risk associated with individual loan applications effectively (Banerjee and Duflo, 2002). Alternatively, it may be the manifestation of a move towards reallocation (or greater allocation) of credit to captured borrowers, in the face of rising competition (Dell'Ariccia and Marquez, 2004).

INSERT Figure 1 about here.

We also take into account the impact of the overall state of the economy (that drives the demand for credit), and regulatory changes on the impact on the CDR of banks. The rationale for controlling for the demand for credit (DEMAND) remains in the significant volatility in India's GDP growth rates since the mid 1990s (see Figure 1), and evidence to suggest that demand may be a binding constraint for the disbursal of credit in the Indian context (Bhaumik and Mukhopadhyay, 1997).

Finally, we control for the second round of reforms experienced by the Indian banking industry since 1998. There is evidence to suggest that the Indian banks were willing to disburse credit more freely once 
the DRTs started functioning effectively, thereby reducing their cost of calling in loans that were in default (Visaria, 2005). We use as the control a dummy variable (RCHANGE) that takes the value 1 for 1999-00 and all subsequent years, and value zero for all years prior to 1999-00.

After taking into consideration these two controls, our specification is as follows:

$$
\begin{gathered}
\mathrm{CDR}_{\mathrm{i}, \mathrm{t}}=\mathrm{f}\left(\mathrm{CDR}_{\mathrm{i}, \mathrm{t}-1}, \text { Branches }_{\mathrm{i}, \mathrm{t}}, \text { Rural }_{\mathrm{i}, \mathrm{t}}, \text { Ownership }_{\mathrm{i}, \mathrm{t}}, \text { ExGOV securities }_{\mathrm{i}, \mathrm{t}-1}, \mathrm{NPA}_{\mathrm{i}, \mathrm{t}-1}, \text { Priority }_{\mathrm{i}, \mathrm{t}-1},\right. \\
\text { Demand } \left._{\mathrm{t}}, \text { Rchange }\right)
\end{gathered}
$$

\section{Data}

The model has been estimated largely using data obtained from the Indian Banks' Association. The data on NPAs were obtained from various issues of Trends and Progress of Banking in India, published by the RBI annually, and the GDP growth rates of India were obtained from the 2003-04 pre-budget Economic Survey published by the Government of India. The empirical analysis involves the use of data from nine financial years: 1995-96 through 2003-04. However, the use of lagged values in the specification results in the use of data from only years 1996-97 through 2003-04 for the regression analysis. The data suggests that although there were 36 foreign banks registered in India during the period, the largest 12 banks accounted for nearly 90 percent of the deposit and asset base of this ownership group. These 12 foreign banks remained in the sample once those with less than two branches were removed; the latter were located in India largely to provide trade credit and services related to cross-border transactions and were not involved in the credit market. The final sample is comprised of 27 state-owned banks, 32 domestic private sector banks (of which 8 are de novo), and 12 foreign banks. Together, they account for approximately 98 percent of the deposits and assets of the Indian banking sector. ${ }^{5}$

INSERT Table 1 about here.

The summary statistics for the data, reported in Table 1 indicate the following: 
Credit-to-deposit ratio: To begin with, it is evident that neither the state-owned banks nor the domestic private banks were lending to their respective capacities. For example, in 2003-04, the combined preemption of deposits by CRR and SLR was less than 35 percent of a bank's deposit, such that an average bank could lend at least up to 65 percent of its deposits. However, at best, an average state-owned bank was lending about 57 percent of its deposits, while a private bank was lending about 60 percent of its deposits. This is consistent with the earlier discussion about "lazy banking."6

More interesting, however, is the distribution of resources between securitized and non-securitized forms of credit. Two measures of CDR are reported, the ratio of non-securitized advances to deposits (CDR1), and the ratio of the sum of non-securitized and securitized loans to deposits (CDR2). The broad measure of credit (CDR2) for state-owned banks did not change significantly over time, rising only slightly from 53.26 percent of deposits in 1995-96 to 56.98 percent of deposits in 2003-04. However, there was a significant difference in the composition of credit across the business cycle, as indicated by the difference between the narrow (i.e., CDR1) and broad measures of credit. Specifically, as growth in the Indian economy slowed down after 1996-97 (Figure 1), there was a sharp decline in CDR1, even though CDR2 increased marginally. The securitized component of credit disbursed by state-owned banks rose from about 7 percent of total credit disbursal in 1995-96 to about 15 percent in 1999-2000. As the Indian GDP growth rate increased again 2003-04, the share of the securitized component in total credit disbursed declined to less than 10 percent.

INSERT Figure 2 about here.

The same pattern involving the changes in the relative importance of securitized and non-securitized credit across the business cycle can be observed for private sector and foreign banks. Indeed, flight to securitized form of lending in the event of a slowdown in GDP growth, and consequent increase in systematic risk, was much more pronounced in non-state-owned banks than in state-owned banks. The share of securitized 
credit (in the total credit disbursed) for private and foreign banks declined from about 5.5 percent and 4.5 percent in 1995-96, respectively, to about 17 percent and 24 percent in 1999-2000. In 2003-04, this share declined to about 11 percent for private banks and to about 7 percent for foreign banks.

It should be noted that securitized credit has two important characteristics. First, there was a reasonably liquid market for short-term corporate securities in India by the second half of the nineties, and, hence, securitized credit from banks, which was raised by companies largely in the form of money market paper, had (perhaps substantially) lower liquidity risk relative to non-securitized credit. Second, commercial papers sold by companies to the banks were mandatorily rated by credit rating agencies and hence if a bank did not have faith in its own ability to identify marginal cases in so far as credit risk was concerned, use of the securitized credit route provided it with a relatively secure means to identifying potential borrowers with acceptable risk profiles. Further, purchase of securities with relatively high credit ratings softens the negative impact on a bank's risk-weighted capital requirement relative to disbursal of nonsecuritized credit to private borrowers with uncertain risk profiles. In view of this, the flight to securitized forms of credit during periods of economic downturn should not be surprising, especially for domestic private banks, most of which were small and lacking credible credit scoring and risk management mechanisms. The highly visible flight of foreign banks to securitized credit, on the other hand, is possibly driven by consideration of their own global credit rating in the face of rising country-specific risk, as GDP growth in the country (i.e., India) declines.

Branch network: It is evident that the Indian banking sector is dominated by large state-owned banks. In 1995-96, an average domestic private bank had less than a tenth of the branch network of an average stateowned bank, and even in 2003-04 an average state-owned bank had more than eight times the geographical coverage of a private bank. ${ }^{7}$ However, while the response of an average foreign bank of the liberalization of the branching regulations was muted, the branch network of an average private bank grew by over 50 percent between 1995-96 and 2003-04. In other words, the main competition for the state- 
owned banks come not from the foreign banks but from the domestic private banks. However, there is some evidence to suggest that this threat to the dominance of the state-owned banks is posed not by the incumbent private banks but by those that came into existence during the nineties (Bhaumik and Dimova, 2004).

Stock exchange listing: As mentioned earlier, since the initiation of reforms, many state-owned banks have disinvested part of their equity to private investors, while retaining controlling equity stake in these banks. In 1995-96, only 1 state-owned bank out of 27 was listed in the stock exchange, but by 2003-04 nearly 3 out of every 5 state-owned banks were stock exchange listed. Since foreign banks in India are effectively branches of their parent banks, it is not surprising that they are not listed on Indian stock exchanges. ${ }^{8}$ However, it is interesting to note that a smaller proportion of domestic private banks (about 45 percent in 2003-04 were listed on stock exchanges than their state-owned counterparts. This is on account of the fact that most domestic private banks in India, especially those that were in existence since the eighties were closely held, usually by trading and business communities. We shall revisit this issue briefly later in this paper.

Regulations: To recapitulate, a bank operating in India has to face three different regulations that are likely to have an impact on their behaviour in the credit market: a part of the deposits mobilized by it is preempted in the form of SLR; it has to disburse a minimum proportion of its credit to the priority sector, and it has to make provisions for NPA on its balance sheet. The first interesting observation in this context is even as the SLR requirement was declining over time, from a high of over 35 percent in the first half of the nineties to the current level of 25 percent, the proportion of deposits held by an average bank in the form of a SLR (i.e., largely government issued) security was actually increasing! This increase was least noticeable for private banks, but very significant for state-owned banks and foreign banks. As such, this indicates that domestic private banks in India are possibly less risk averse than their state-owned and foreign counterparts. 
It is also instructive to see that while the domestic banks, especially those that are state-owned, were increasing their exposure to the priority sector (as a percentage of the total credit disbursed) over time, the exposure of foreign banks to the priority sector remained roughly the same over time. Going by the behaviour of the foreign banks, that are least likely to be swayed by moral suasion of the RBI, exposure to the priority sector is viewed as a risky endeavour, such that facing penalties for not meeting the priority sector regulation is preferable to actually lending to this sector, and thereby being exposed to both higher capital cost and NPA-related risk. Recall that in 2003-04, for example, a foreign bank was expected to disburse 32 percent of its credit to the priority sector, and the actual proportion of its credit disbursed by an average foreign bank to this sector was about 21 percent. Widespread default with respect to the RBI's priority sector norms, that is evident from the summary statistics, raises the question as to whether the

penalty imposed by the central bank on errant commercial banks has any impact on the latter's behaviour. ${ }^{9}$

Non-performing assets: Not surprisingly, the NPA on the balance sheet of an average foreign bank, as a percentage of its total assets, is lower than the NPA on the balance sheet of a domestic bank. A foreign bank is expected to have better credit appraisal techniques that an emerging market bank, and might also be in a position to "cherry pick" the most credit worthy borrowers in an emerging market. However, it is interesting to note that while the NPA on the balance sheets of state-owned banks declined over time, those on the balance sheets of foreign banks increased, such that, by 2003-04, an average state-owned bank had roughly the same NPA on its balance sheet as an average foreign bank. This is consistent with research that has discovered convergence between performance of state-owned banks and foreign banks on other fronts (Bhaumik and Dimova, 2004).

\section{Results and Discussion}

The regression results are reported in Tables 2 and 3. The dependent variable for Table 2 is the narrow measure of credit, namely, non-securitized credit alone as a proportion of deposits (CDR1). The dependent 
variable for Table 3 is the broader measure of credit, namely the sum of non-securitized and securitized credit as a proportion of deposits (CDR2). Both tables report the coefficient estimates and the robust standard errors. As mentioned earlier, we estimate equation (3), which represents a dynamic panel model, using the methodology proposed by Blundell and Bond (1998). We report the coefficient estimates for state-owned banks, domestic private banks, all domestic banks, and foreign banks. ${ }^{10}$

INSERT Tables 2 and 3 about here.

It is evident from the test statistics that the choice of the econometric technique and model specification are appropriate for the data. The F-statistics suggest that the model fits the data well. Importantly, the fit, as evident from the significance of the coefficient estimates, is the best for domestic private banks that are vulnerable neither to moral suasion, if any, nor to the considerations that foreign banks have about their own global credit ratings. In other words, the portfolio-choice model, which is based on the assumption that the bank is a mean-variance optimizer in an asset space that is exhaustive, does fit well the data for the banks that are most likely to fit this profile in India. The chi-square statistics associated with the Hansen's test indicate that the instruments used for the Blundell and Bond methodology are appropriate, and those associated with tests for autocorrelation indicate that the econometric modelling has corrected for possible autocorrelation.

The results indicate that for an average state-owned bank past lending has a statistically significant impact on their lending in the present, when the measure of lending is CDR1, i.e., non-securitized lending alone (Table 2). This is consistent with the finding of Banerjee and Duflo (2002), but the coefficient of 0.30 for the lagged dependent variable indicates that the economic implication of this persistence may not be very significant. Importantly, this persistence disappears once we take into consideration the broader measure of credit disbursal (Table 3). 
The coefficient estimates for state-owned banks differ for CDR1 and CDR2 in two other ways. The narrow measure of credit disbursal by these banks is positively influenced by the second generation banking reforms that facilitated the calling in of doubtful loans by way of the DRTs, and (roughly) coincided with the removal of requirements to form syndicates mandatorily to lend to large borrowers (i.e., for sums exceeding INR 500 million). The second generation of reforms did not seem to have had much of an impact on the broader measure of credit disbursal. Surprisingly, however, NPA accumulation on the balance sheet adversely affected CDR2, the wider measure, without having any impact on CDR1, the narrower measure.

The private banks too exhibit persistence between past and present credit, and for them this persistence is visible for both the narrow and broad measure of credit. Indeed, the extent of persistence is stronger for the private banks than for the state-owned banks. Further, for the former, the degree of persistence is higher for CDR2 (Table 3) than for CDR1 (Table 2). The rationale for this possibly lies in the fact that most private banks in India, with the obvious exceptions of the de novo ones, are community based, and are concentrated geographically, with close connections with companies belonging to allied trading and business communities. This line of argument is consistent with the previously reported findings of Berger et al. (2005) that suggest that private banks in India have a comparative advantage in providing credit to opaque (i.e., closely held private) firms. These community-based links with (a large section of) potential borrowers, which usually co-exists with well-specified albeit informal norms for debt recovery, is also a possible reason as to why the second generation of reforms did not affect the credit disbursal behaviour of private banks, even though these reforms had a significant impact on the behaviour of state-owned (and foreign) banks.

Given their relatively small geographical coverage, it is not surprising that the size of the branch network would be a more important factor influencing credit disbursal by private banks than by state-owned banks. This is borne out by the coefficient estimates reported in both Tables 2 and 3. It is interesting to note that 
private banks listed in the stock exchanges are more aggressive in the credit market than their non-listed counterparts. In part, this might be a manifestation of the urge of the management of listed private banks to capture greater market share that is one possible indicator of performance. But this result might also have been driven to a large extent by the experiences of the de novo banks that are listed and that grew aggressively after 1995-96.

The regression results also indicate that past "distance" of the private banks from the required minimum holding of SLR securities has a significant impact on credit disbursal behaviour in the present. Specifically, private banks that are further away from the required minimum, i.e., are more risk averse, are likely to disburse less credit, irrespective of how we measure credit (i.e., CDR1 in Table 2 or CDR2 in Table 3).

One of the problems of estimating the model highlighted in equation (3) is that the differences in the characteristics of the banks across ownership groups is higher than the differences in these characteristics within any ownership group. Hence, samples that include data on only state-owned or private banks may not be rich in variations with respect to either credit-to-deposit ratio or the bank-level characteristics that explain inter-bank difference in this ratio. We, therefore, pool together state-owned and private banks, and use this larger sample of all domestic banks, with greater inter-bank variation, to estimate our model. It is evident from both Tables 2 and 3 that our model fits this pooled sample fairly well. Our results indicate that the credit-to-deposit ratio of an average domestic Indian bank is influenced by past credit-to-deposit ratio $(+)$, size of the branch network $(+)$, stock exchange listing $(+)$, risk averseness as measured by the past "distance" from the SLR floor (-), accumulated NPA on the balance sheet (-), and the second generation reforms that facilitated loan recovery through the use of the DRTs. These estimates are less significant for the model that uses the wider measure of credit (CDR2 in Table 3) which is not surprising on account of the lower variation in CDR2 relative to CDR1. However, overall, the results are robust across the two measures of credit. 
Finally, our model does not explain inter-bank variation in credit disbursal behaviour of foreign banks, when the narrow measure of credit (i.e., CDR1) is taken into consideration (Table 2). However, the coefficient estimates reported in Table 3 indicate that disbursal of the wider measure of credit (i.e., CDR2) in the present is negatively affected by "distance" from the required minimum exposure to the priority sector in the past. Since a large distance from this required minimum implies a larger penalty, this suggests that the priority sector norm of the RBI, together with the penalty associated with noncompliance with this norm, does after all affect the credit market behaviour of foreign banks, something that was not obvious from the descriptive statistics reported in Table 1.

As with the state-owned banks, credit disbursal by foreign banks, as measured by CDR2, was positively affected by the second generation of banking reforms (Table 3). This indicates that a more liberal bankruptcy law that would allow quicker liquidation of bankrupt companies, and perhaps accord seniority to debtors over the others, is likely to induce the foreign banks to take a larger credit exposure to India.

\section{Concluding Remarks}

In this paper, we introduce a portfolio-choice framework to model the credit market behaviour of banks operating in an emerging market, and then estimate the resultant dynamic panel model using bank-level data from India. In the process, we are able to distinguish between the credit disbursal behaviour of stateowned banks, private sector banks, and foreign banks that operate in India on a level playing field. Not surprisingly, our model best explains the behaviour of private banks that neither face the legacy and moral suasion of the state-owned banks, nor are sensitive to issues like country-risk and global credit rating like the foreign banks. The model fits the data for the pooled sample of all domestic banks fairly well, thereby raising encouraging possibilities that such portfolio-choice models can be used to analyze credit disbursal behaviour of banks in other emerging market contexts. 
The empirical analysis indicates that there is some degree of year-on-year persistence in the exposure of domestic banks to the credit market. This persistence is greater for the private banks, most of which have strong and long-term links with specific business communities. Credit disbursal is positively affected by stock exchange listing of banks - albeit more for private banks than for state-owned banks - and negatively affected by the degree of risk aversion of these financial intermediaries. There is also evidence to suggest that the second round of banking reforms have had a positive impact on the proportion of deposits that the banks disburse as credit. This is especially true for state-owned banks, which were most affected by incidence of doubtful loans in the nineties, and the foreign banks, who are likely to be most sensitive to the accumulation of such assets on their balance sheets. Finally, there is evidence to suggest that the NPA provisioning regulation of the RBI discourage credit disbursal. As such, the results are consistent with our prior expectations that are based on the underlying portfolio choice model.

An important implication of the empirical analysis that is only indirectly evident from the regression analysis but obvious from the summary statistics reported in Table 1 is that inter-year variation in creditto-deposit ratio for all banks operating in India was much lower when securitized forms of credit delivery were taken into account, and the coefficient of variation within each year was much lower for the broader measure of credit (CDR2) than the narrower measure of credit (CDR1). This is also consistent with the better fit for the model that explains variations in CDR1 (Table 2), as evident from the significance of the coefficient estimates, than for the model that explains variations in CDR2 (Table 3). In other words, an average bank in India is more likely to reach to changes in systematic (credit) risk by altering the allocation of resources between securitized and non-securitized forms of credit, than between credit and other asset classes (Figure 2). In part, this may be a reflection of the asset choices available to the banks, and the regulations governing a bank's exposure to alternative forms of assets like equity. However, there is prima facie evidence that financial intermediation in India may significantly benefit from further development of the market for corporate securities, especially now that Indian banks are allowed to provide long term credit, even as the market for long term corporate bonds remains underdeveloped. 
Overall, the results indicate that while the liberalisation of the banking industry has led to a significant improvement in the relative performance of the domestic banks (Sarkar, Sarkar and Bhaumik, 1998; Bhaumik and Dimova, 2004), greater competition and the implementation of prudential norms have also made these banks somewhat circumspect in so far as credit disbursal is concerned. The risk averseness of the banks, which is correlated with the volume of NPA on their balance sheets and is manifested by their aversion to priority sector credit and by their desire to hold sovereign low-yield debt securities, is offset, at least in part, by developments that facilitate access to capital (e.g., stock market listing) and enforcement of debt covenants to recover bad loans (e.g., second generation of banking reforms). Further, the reduction of liquidity risk on account of credit disbursal by way of securities, as opposed to traditional bank loans, also enhances the willingness of an average domestic bank in India to lend. However, given that providing the public sector banks greater access to equity capital would involve further dilution of the state's equity holding, a move that is fraught with political problems, and given that smaller firms usually have limited capability to borrow by way of debt securities, our results have negative implications for the ability of SMEs to depend on bank borrowing for survival and growth. The prognosis may be even worse for startup SMEs that do not have established relationships with commercial banks. The policy implication of our results, therefore, is that the government would have to strengthen the institutional aspects of micro-credit delivery systems to facilitate the entry, survival and growth of (typically small) firms that find it difficult to access credit from the commercial banking sector. 


\section{References}

Acemoglu, Daron (2001) Credit market imperfections and persistent unemployment, European Economic Review, 45:4-6, 665-79.

Ashcraft, Adam B. (2001) Do tougher bank capital requirements matter? New evidence from the eighties. Mimeo, Federal Reserve Bank of New http://www.ny.frb.org/research/economists/ashcraft/capital_0723.pdf.

Banerjee, Abhijit. V. and Esther Duflo (2002) The nature of credit constraints: Evidence from an Indian bank, Working Paper No. 02-05, Massachusetts Institute of Technology, Cambridge, Massachusetts.

Banerjee, Abhijit V., Shawn Cole and Esther Duflo (2003) Bank financing in India, International Monetary Fund, http://www.imf.org/external/np/apd/seminars/2003/newdelhi/banerjee.pdf.

Bell, Clive and Peter L. Rousseau (2001) Post-independence India: a case of finance-led industrialization? Journal of Development Economics, 65:1, 153-75.

Berger, Allen N. and Gregory F. Udell (1994) Did risk-based capital allocate bank credit and cause a 'credit crunch' in the US? Journal of Money, Credit and Banking, 26, 585-628.

Berger, Allen N., Leora F. Klapper, Maria S. M. Peria and Rita Zaidi (2005) The effects of bank ownership type on banking relationships and multiple banking in developing countries: Detailed evidence from India. Mimeo, The World Bank, Washington, D.C., http://www.diw.de/english/produkte/veranstaltungen/banking2005/docs/Berger_et_al_DIW_Conference.p df.

Bhaumik, Sumon K and Hiranya Mukhopadhyay (1997) Has credit crunch led to industrial stagnation? A disequilibrium approach. Economic and Political Weekly, 32:18, 964-967.

Bhaumik, Sumon K and Paramita Mukherjee (2002) The Indian banking sector: A commentary, In: Parthasarathi Banerjee and Frank-Jurgen Richter (Eds.) Economic Institutions in India: Sustainability under Liberalization and Globalization, Palgrave Macmillan, London, pp. 71-98.

Bhaumik, Sumon K and Ralitza Dimova (2004) How important is ownership in a market with a level playing field? The Indian banking sector revisited, Journal of Comparative Economics, 32:1, 165-180.

Blundell, Robert and Stephen Bond (1998) Initial conditions and moment restrictions in dynamic panel data models. Journal of Econometrics, 87:1, 115-143.

Bulir, Ales (1998) Business cycle in Czechoslovakia under central planning: Were credit shocks causing it? Journal of Comparative Economics, 26:2, 226-45.

Clarke, George, Robert Cull, Laura D'Amato and Andrea Molinari (1999) The effect of foreign entry on Argentina's domestic banking sector, Policy Research Working Paper 2158, The World Bank, Washington, D.C.

Clarke, George, Robert Cull and Maria S. M. Peria (2001) Does foreign bank penetration reduce access to credit in developing countries? Evidence from asking borrowers, Mimeo, Development Research Group, The World Bank, Washington, D.C. 
Clarke, George, Robert Cull and Maria S. M. Peria and Susana M. Sanchez (2002) Bank lending to small businesses in Latin America: Does bank origin matter? Mimeo, The World Bank, Washington, D.C.

Clarke, George R.G., Juan Miguell Crivelli and Robert Cull (2005) The direct and indirect impact of bank privatization and foreign entry on access to credit in Argentina's provinces. Journal of Money, Credit and Banking, 29, 5-29.

Da Rin, Marco and Thomas Hellman (2002) Banks as catalysts for industrialization. Journal of Financial Intermediation, 11:4, 366-397.

Dell'Ariccia, Giovanni and Robert Marquez (2004) Information and bank credit allocation. Journal of Financial Economics, 72:1, 185-214.

Furfine, Craig (2001) Bank portfolio allocation: The impact of capital requirements, regulatory monitoring and economic conditions. Journal of Financial Services Research, 20:1, 33-56.

Gertler Mark and Simon Gilchrist (1993) The cyclical behaviour of short-term business lending: Implications for financial propagation mechanisms, European Economic Review, 37:2-3, 623-31.

Ghosh, Dhruva N. (1988) Banking: Lessons from the Indian experience. SBI Monthly Review 28, 531543.

Godlewski, Chistophe J. (2004) Capital regulation and credit risk taking: Empirical evidence from banks in emerging market economies. Mimeo, Institut d'Etudes Politiques, Universite Robert Schuman, France.

Gorton, Gary and Frank Schmid (1999) Corporate governance, ownership dispersion and efficiency: Empirical evidence from Austrian cooperative banking, Journal of Corporate Finance, 5, 119-40.

Hirshey, Mark (1999) Managerial equity ownership and bank performance, Economics Letters, 64, 20913.

Indian Banks’ Association (1995-2004) Performance Highlights of Banks.

International Monetary Fund (2000) Bulgaria: Selection issues and statistical appendix. IMF Staff Country Report, 00/54.

Jeong, Woocheon, Kem O. Kymn and Christine J. Kymn (2003) The long-run interdependence of bankhealth, investment-oriented bank loans, and economic performance: A time-series analysis, The Quarterly Review of Economics and Finance, 43:1, 11-30.

Ketkar, Kusum (1993) Public sector banking, efficiency and economic growth in India, World Development, 21:10, 1685-97.

Ma, Chien-Hui and Bruce D Smith (1996) Credit market imperfections and economic development: Theory and evidence, Journal of Development Economics, 48:2, 351-87.

Mayer, Colin (2000) Financial systems, corporate finance, and economic development. In: R. Glen Hubbard (Ed.) Asymmetric information, corporate finance and investment. Chicago: University of Chicago Press, pp. 307-332. 
Mian, Atif (2006) Distance constraints: The limits of foreign lending in poor economies. Journal of Finance, forthcoming.

Randall, Richard E. (Ed.) (1993) Safeguarding the Banking System in an Environment of Financial Cycles, Federal Reserve Bank of Boston.

Reddy, Y. Venugopal (1998) Financial sector reform: Review and prospects. Keynote address at the conference on "Growth, governance and empowerment: The future of India's economy," University of California, Santa Cruz.

Reserve Bank of India, Trends and Progress of Banking in India, various issues.

Sabirianova, Klara, Jan Svejnar and Katherine Terrell (2005) Distance to efficiency frontier and foreign direct investment spillovers. Journal of the European Economic Association, 3:2-3, 576-586.

Sapienza, Paola (2004) The effects of government ownership on bank lending. Journal of Financial Economics, 72:2, 357-384.

Sarkar, Jayati and Pradeep Agarwal (1997) Banking: The challenges of deregulation. In: Kirit Parikh (Ed.) India Development Report, New Delhi: Oxford University Press.

Sarkar, Jayati, Subrata Sarkar and Sumon K. Bhaumik (1998) Does ownership always matter? Evidence from the Indian banking industry? Journal of Comparative Economics, 26, 262-281.

Shirai, Sayuri and Prithipal Rajsekaran (2001) Is India's banking sector reform successful from the perspective of the governance of the banking system? Mimeo, Economic and Social Commission for Asia and the Pacific.

Thakor, Anjan V. (1996) Capital requirements, monetary policy and aggregate bank lending: Theory and empirical evidence. Journal of Finance, 51, 279-324.

Visaria, Sujata (2005) Legal reform and loan repayment: The microeconomic impact of debt recovery tribunals in India. Mimeo, Columbia http://www.columbia.edu/\%7Esv262/SVisariaJMPaperJan2005.pdf. 
Figure 1

GDP and industrial growth in India: 1996-97 to 2003-04

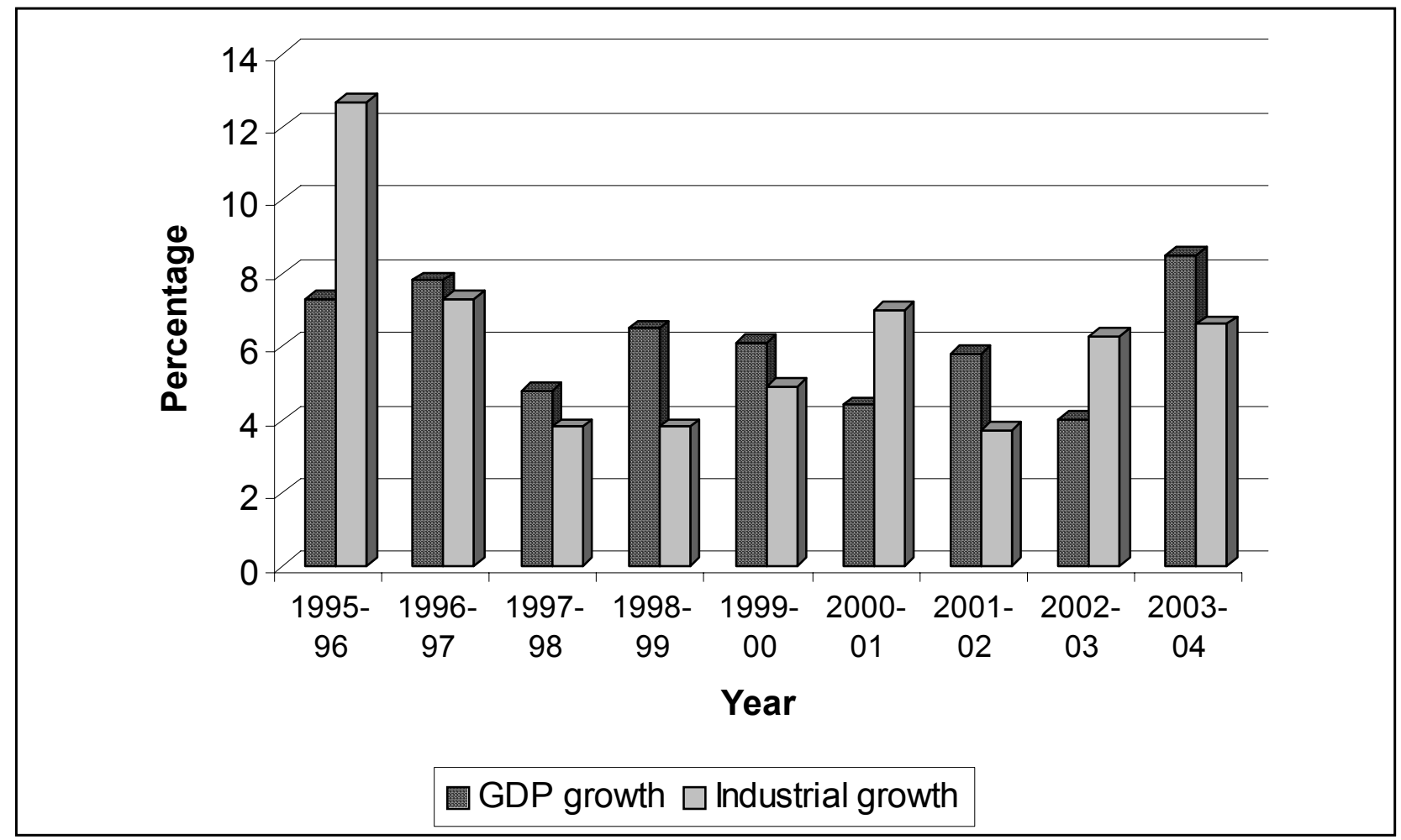

Source : Economic Survey, Government of India, 2004-05 
Table 1

Descriptive Statistics

\begin{tabular}{|c|c|c|c|c|c|c|c|c|c|}
\hline & \multicolumn{3}{|c|}{ State-owned banks } & \multicolumn{3}{|c|}{ Private sector banks } & \multicolumn{3}{|c|}{ Foreign banks } \\
\hline & $1995-96$ & $\begin{array}{l}1999- \\
2000\end{array}$ & 2003-04 & $1995-96$ & $\begin{array}{l}1999- \\
2000\end{array}$ & 2003-04 & $\begin{array}{l}1995- \\
96\end{array}$ & $\begin{array}{l}1999- \\
2000\end{array}$ & 2003-04 \\
\hline $\begin{array}{l}\text { Credit-to- } \\
\text { deposit ratio } 1\end{array}$ & $\begin{array}{r}0.49 \\
(0.07)\end{array}$ & $\begin{array}{r}0.46 \\
(0.06)\end{array}$ & $\begin{array}{r}0.51 \\
(0.11)\end{array}$ & $\begin{array}{r}0.58 \\
(0.14)\end{array}$ & $\begin{array}{r}0.49 \\
(0.09)\end{array}$ & $\begin{array}{r}0.53 \\
(0.12)\end{array}$ & $\begin{array}{r}0.90 \\
(0.32)\end{array}$ & $\begin{array}{r}0.74 \\
(0.29)\end{array}$ & $\begin{array}{r}0.94 \\
(0.41)\end{array}$ \\
\hline $\begin{array}{l}\text { Credit-to- } \\
\text { deposit ratio } 2\end{array}$ & $\begin{array}{r}0.53 \\
(0.07)\end{array}$ & $\begin{array}{r}0.54 \\
(0.06)\end{array}$ & $\begin{array}{r}0.56 \\
(0.11)\end{array}$ & $\begin{array}{r}0.61 \\
(0.14)\end{array}$ & $\begin{array}{r}0.59 \\
(0.10)\end{array}$ & $\begin{array}{r}0.60 \\
(0.13) \\
\end{array}$ & $\begin{array}{r}0.95 \\
(0.32)\end{array}$ & $\begin{array}{r}0.97 \\
(0.32)\end{array}$ & $\begin{array}{r}1.01 \\
(0.39) \\
\end{array}$ \\
\hline $\begin{array}{l}\text { Total } \\
\text { branches }\end{array}$ & $\begin{array}{r}1638.37 \\
(1673.51) \\
\end{array}$ & $\begin{array}{r}1714.25 \\
(1705.56) \\
\end{array}$ & $\begin{array}{r}1703.48 \\
(1672.95) \\
\end{array}$ & $\begin{array}{r}130.57 \\
(120.29) \\
\end{array}$ & $\begin{array}{r}167.30 \\
(124.15) \\
\end{array}$ & $\begin{array}{l}201.41 \\
(45.43)\end{array}$ & $\begin{array}{r}12.16 \\
(16.70)\end{array}$ & $\begin{array}{r}11.41 \\
(11.46)\end{array}$ & $\begin{array}{r}16.41 \\
(20.06)\end{array}$ \\
\hline $\begin{array}{l}\% \text { of non- } \\
\text { urban branch }\end{array}$ & $\begin{array}{r}66.99 \\
(4.85) \\
\end{array}$ & $\begin{array}{r}63.41 \\
(5.95) \\
\end{array}$ & $\begin{array}{r}61.87 \\
(6.60) \\
\end{array}$ & $\begin{array}{r}47.16 \\
(28.07) \\
\end{array}$ & $\begin{array}{r}51.26 \\
(18.72) \\
\end{array}$ & $\begin{array}{r}45.43 \\
(19.08) \\
\end{array}$ & 0 & 0 & 0 \\
\hline $\begin{array}{l}\text { \% listed at a } \\
\text { stock } \\
\text { exchange }\end{array}$ & $\begin{array}{r}3.70 \\
(19.24)\end{array}$ & $\begin{array}{r}22.22 \\
(42.36)\end{array}$ & $\begin{array}{r}59.25 \\
(50.07)\end{array}$ & $\begin{array}{r}6.06 \\
(24.23)\end{array}$ & $\begin{array}{r}30.00 \\
(46.60)\end{array}$ & $\begin{array}{r}44.82 \\
(50.61)\end{array}$ & 0 & 0 & 0 \\
\hline $\begin{array}{l}\% \text { of deposits } \\
\text { in SLR }\end{array}$ & $\begin{array}{r}30.19 \\
(5.37)\end{array}$ & $\begin{array}{l}34.32 \\
(6.16)\end{array}$ & $\begin{array}{l}42.28 \\
(6.90)\end{array}$ & $\begin{array}{l}22.55 \\
(3.17)\end{array}$ & $\begin{array}{r}27.18 \\
(4.70)\end{array}$ & $\begin{array}{l}33.88 \\
(6.34) \\
\end{array}$ & $\begin{array}{l}31.07 \\
(6.10)\end{array}$ & $\begin{array}{r}43.56 \\
(13.26) \\
\end{array}$ & $\begin{array}{r}49.53 \\
(20.18) \\
\end{array}$ \\
\hline $\begin{array}{l}\% \text { of credit to } \\
\text { priority sector }\end{array}$ & $\begin{array}{r}26.79 \\
(10.45)\end{array}$ & $\begin{array}{l}34.06 \\
(6.09)\end{array}$ & $\begin{array}{r}37.81 \\
(5.36)\end{array}$ & $\begin{array}{r}28.46 \\
(11.98)\end{array}$ & $\begin{array}{r}29.95 \\
(10.98)\end{array}$ & $\begin{array}{r}32.05 \\
(10.59)\end{array}$ & $\begin{array}{r}22.02 \\
(9.96)\end{array}$ & $\begin{array}{r}21.48 \\
(13.42)\end{array}$ & $\begin{array}{r}21.07 \\
(9.79)\end{array}$ \\
\hline $\begin{array}{l}\text { Gross NPA to } \\
\text { total assets }\end{array}$ & $\begin{array}{r}8.11 \\
(3.31) \\
\end{array}$ & $\begin{array}{r}5.99 \\
(2.29) \\
\end{array}$ & $\begin{array}{r}3.42 \\
(1.46)\end{array}$ & $\begin{array}{r}3.69 \\
(2.82) \\
\end{array}$ & $\begin{array}{r}4.67 \\
(2.48) \\
\end{array}$ & $\begin{array}{r}4.11 \\
(3.42) \\
\end{array}$ & $\begin{array}{r}1.04 \\
(1.10) \\
\end{array}$ & $\begin{array}{r}2.80 \\
(1.77) \\
\end{array}$ & $\begin{array}{r}3.33 \\
(3.24) \\
\end{array}$ \\
\hline $\begin{array}{l}\text { Number of } \\
\text { banks }\end{array}$ & 27 & 27 & 27 & 33 & 30 & 29 & 12 & 12 & 12 \\
\hline
\end{tabular}

Note: The values within the parentheses are standard deviations.

Note again, that all foreign banks are not listed at Indian stock exchanges, but all of them are listed at overseas stock exchanges 
Figure 2

Exposure of Indian banks to corporate debt instruments

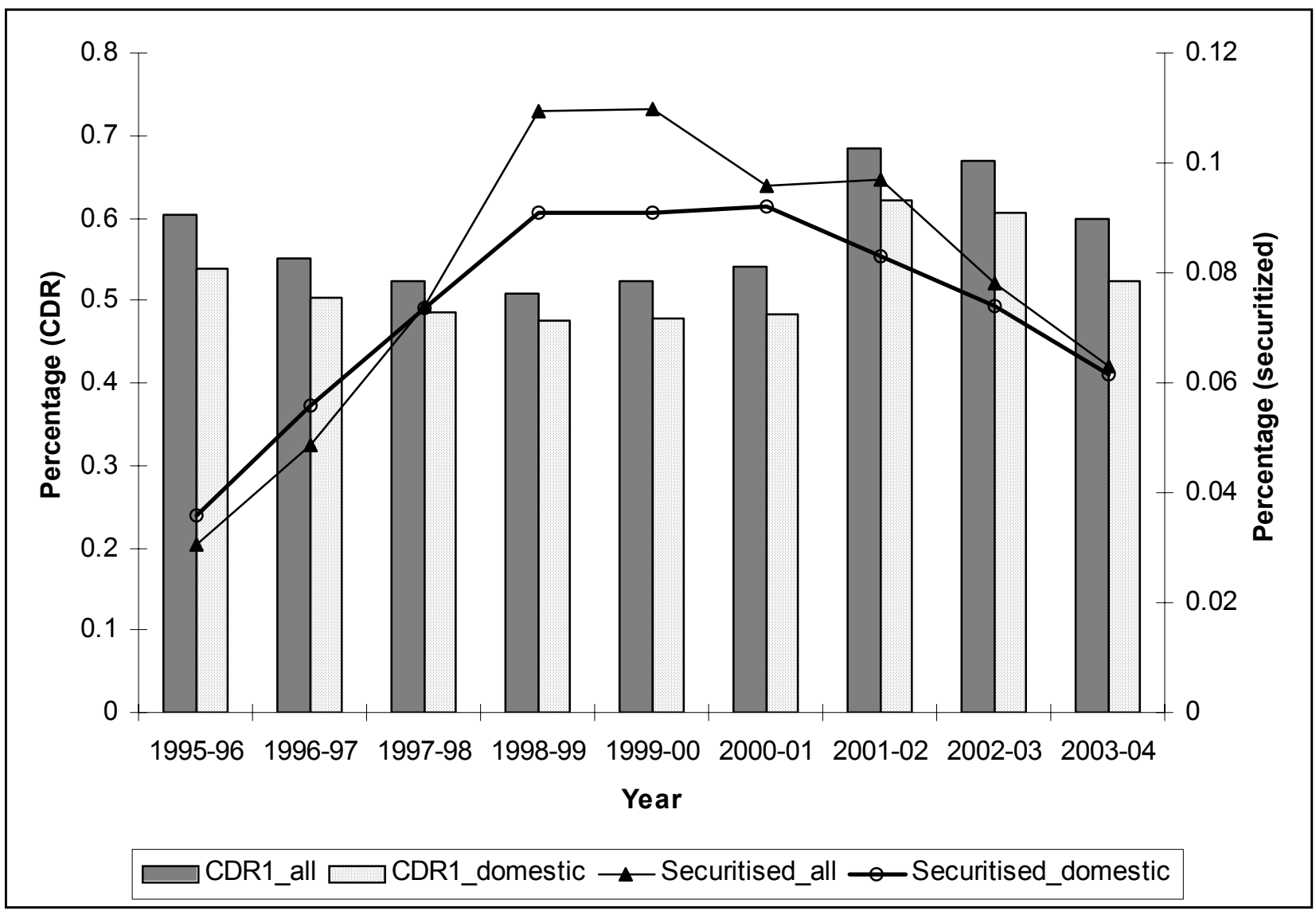


Table 2

\section{Determinants of credit disbursal}

Dependent variable: Credit-to-deposit ratio when credit includes non-securitized credit alone

\begin{tabular}{|l|l|l|l|l|}
\hline & State & Private & Domestic & Foreign \\
\hline Lagged dependent variable & $0.3097^{*}$ & $0.3936^{* *}$ & $0.5203 * * *$ & 0.1677 \\
& $(0.1637)$ & $(0.1431)$ & $(0.0937)$ & $(0.2612)$ \\
\hline Total branches & 0.0000 & $0.0010^{*}$ & $0.0004^{*}$ & -0.0002 \\
& $(0.0001)$ & $(0.0005)$ & $(0.0002)$ & $(0.0057)$ \\
\hline \% of non-urban branches & 0.0045 & -0.0003 & -0.0000 & \\
& $(0.0042)$ & $(0.0002)$ & $(0.0003)$ & \\
\hline Dummy for stock exchange listing & 0.0432 & $0.0729 *$ & $0.0767 * *$ & \\
& $(0.0479)$ & $(0.0431)$ & $(0.0322)$ & \\
\hline Lagged distance from the minimum required & -0.0006 & $-0.0059 * *$ & $-0.0041 * *$ & 0.0015 \\
exposure to SLR securities & $(0.0026)$ & $(0.0026)$ & $(0.0016)$ & $(0.0023)$ \\
\hline Lagged distance from the minimum & -0.0001 & 0.0038 & 0.0008 & -0.0033 \\
exposure to priority sector lending & $(0.0006)$ & $(0.0031)$ & $(0.0012)$ & $(0.0041)$ \\
\hline Lagged gross NPA to total assets & -0.0053 & -0.0012 & $-0.0051 * *$ & -0.0140 \\
& $(0.0034)$ & $(0.0047)$ & $(0.0025)$ & $(0.0091)$ \\
\hline GDP growth rate & 0.0006 & -0.0006 & 0.0006 & 0.0006 \\
& $(0.0022)$ & $(0.0034)$ & $(0.0017)$ & $(0.0139)$ \\
\hline Dummy for 2 ${ }^{\text {nd }}$ generation reforms & $0.0250 *$ & 0.0304 & $0.0371 * *$ & -0.0419 \\
& $(0.0139)$ & $(0.0225)$ & $(0.0149)$ & $(0.1281)$ \\
\hline & & & & \\
\hline F-statistic & 3.95 & 7.99 & 10.96 & 6.76 \\
(Prob $>$ F-statistic) & $(0.00)$ & $(0.00)$ & $(0.00)$ & $(0.00)$ \\
\hline Hansen test & 21.39 & 26.14 & 51.77 & 6.58 \\
(Prob $>$ chi-square) & $(1.00)$ & $(0.99)$ & $(0.44)$ & $(1.00)$ \\
\hline AR(1) & -1.31 & -1.25 & -1.57 & -1.08 \\
(Prob $>$ z) & $(0.19)$ & $(0.21)$ & $(0.12)$ & $(0.28)$ \\
\hline AR(2) & -1.32 & 0.69 & 0.46 & -0.50 \\
(Prob $>$ z) & $(0.18)$ & $(0.49)$ & $(0.64)$ & $(0.61)$ \\
\hline Number of observations & 189 & 192 & 381 & 74 \\
\hline Number of banks & 27 & 32 & 59 & 12 \\
\hline Note: & & & \\
\hline
\end{tabular}

Note: The values within the parentheses are standard errors.

$* * *, * *$ and $*$ indicate significance at $1 \%, 5 \%$ and $10 \%$ levels, respectively. 
Table 3

\section{Determinants of credit disbursal}

Dependent variable: Credit-to-deposit ratio when credit includes both non-securitized and securitized credit

\begin{tabular}{|l|l|l|l|l|}
\hline & State & Private & Domestic & Foreign \\
\hline Lagged dependent variable & 0.0263 & $0.4796^{* * *}$ & $0.5158^{* * *}$ & 0.1459 \\
& $(0.3223)$ & $(0.1179)$ & $(0.0961)$ & $(0.2447)$ \\
\hline Total branches & -0.0000 & $0.0008^{*}$ & 0.0002 & -0.0089 \\
& $(0.0001)$ & $(0.0004)$ & $(0.0002)$ & $(0.0073)$ \\
\hline \% of non-urban branches & 0.0060 & -0.0003 & $-9.01 \mathrm{e}-06$ & \\
& $(0.0041)$ & $(0.0002)$ & $(0.0003)$ & \\
\hline Dummy for stock exchange listing & 0.0483 & 0.0426 & 0.0429 & \\
& $(0.0423)$ & $(0.0450)$ & $(0.0283)$ & \\
\hline Lagged distance from the minimum & -0.0004 & $-0.0057 * *$ & $-0.0034 * *$ & 0.0013 \\
required exposure to SLR securities & $(0.0027)$ & $(0.0027)$ & $(0.0016)$ & $(0.0020)$ \\
\hline Lagged distance from the minimum & -0.0001 & 0.0032 & 0.0009 & $-0.0111 *$ \\
exposure to priority sector lending & $(0.0007)$ & $(0.0024)$ & $(0.0010)$ & $(0.0062)$ \\
\hline Lagged gross NPA to total assets & $-0.0073 *$ & -0.0069 & $-0.0062 * *$ & -0.0087 \\
& $(0.0042)$ & $(0.0061)$ & $(0.0026)$ & $(0.0057)$ \\
\hline GDP growth rate & -0.0003 & -0.0030 & -0.0017 & 0.0024 \\
& $(0.0023)$ & $(0.0029)$ & $(0.0016)$ & $(0.0272)$ \\
\hline Dummy for 2 ${ }^{\text {nd }}$ generation reforms & 0.0255 & 0.0490 & $0.0340 * *$ & $0.1396 *$ \\
& $(0.0188)$ & $(0.0305)$ & $(0.0159)$ & $(0.0708)$ \\
\hline & & & & \\
\hline F-statistic & 7.57 & 6.01 & 7.31 & 3.56 \\
(Prob $>$ F-statistic) & $(0.00)$ & $(0.00)$ & $(0.00)$ & $(0.02)$ \\
\hline Hansen test & 17.17 & 21.33 & 52.28 & 9.74 \\
(Prob $>$ chi-square) & $(1.00)$ & $(1.00)$ & $(0.42)$ & $(1.00)$ \\
\hline AR(1) & -0.87 & -1.35 & -1.70 & -1.13 \\
(Prob $>$ z) & $(0.00)$ & $(0.17)$ & $(0.09)$ & $(0.26)$ \\
\hline AR(2) & -2.12 & 1.02 & 0.21 & -1.15 \\
(Prob $>$ z) & $(0.03)$ & $(0.30)$ & $(0.83)$ & $(0.25)$ \\
\hline Number of observations & 189 & 192 & 381 & 65 \\
\hline Number of banks & 27 & 32 & 59 & 12 \\
\hline Note: & & & \\
\hline
\end{tabular}

Note: The values within the parentheses are standard errors.

$* * *, * *$ and $*$ indicate significance at $1 \%, 5 \%$ and $10 \%$ levels, respectively. 


\section{Endnotes}

${ }^{1}$ As mentioned earlier, there is some evidence to suggest that the threat of political persecution might have limited the willingness of the managers of public sector banks to make a break with the past (Banerjee and Duflo, 2002), but one has to be careful about generalizing the result obtained using information provided by one public sector bank. At the same time, the empirical literature on the Indian banking sector (e.g., Bhaumik and Dimova, 2004) suggests that the public sector banks were responding to the changed policy and competition paradigm, and that, by the end of the 1990s, ownership itself could no longer explain cross-sectional variations in profitability of banks. Since catching up with the profitability and, conversely, cost efficiency, of the private sector and foreign banks requires that the public sector banks be able to allocate their resources efficiently, there is prima facie evidence to suggest that the public sector banks too are behaving as optimizing agents.

${ }^{2}$ In India, for example, a bank is allowed to charge up to 400 basis points over and above its prime lending rate to account for increasing levels of risk.

${ }^{3}$ It is stylized in the literature to control for the size of the bank in the specification, in a variety of contexts. The usual measures of a bank's size are it's the stock of its deposits and the stock of its assets. However, the number of branches of a bank are, not surprisingly, highly collinear with both the deposit base and the asset size of the bank. For our sample, the correlation coefficient was greater than 0.95 for all the years in the sample. Hence, we did not include deposits or assets as a control variable in our specification.

${ }^{4}$ The use of these distance functions is fairly stylized in the empirical literature on industrial organization, especially in the context of trade and foreign direct investment. In most cases, these analyses use distance from a performance (e.g., sales growth or total factor productivity) frontier as a determinant of spillover from foreign direct investment among domestic firms (e.g., Sabirianova, Svejnar and Terrell, 2005).

${ }^{5}$ Note that a number of state-owned banks in India have "disinvested" part of their equity to private investors, and are, therefore, listed at stock exchanges. For example, the State Bank of India, the largest state-owned bank that alone accounts for more than 15 percent of the deposit and credit markets in India is listed at both domestic stock exchanges and at the New York Stock Exchange. Its stocks are among the most liquid at Indian stock exchanges and among Indian American Depository Receipts bought and sold in overseas markets. However, the controlling share for each of these banks remains in the hands of the government.

${ }^{6}$ The high credit-to-deposit ratio of the foreign banks, which ranged between 95 percent and 101 percent of their deposit base, on average was on account of the fact that deposits raised within India is a fraction of the amount at their disposal which they can disburse in the credit market. Foreign banks in India are branches of the respective parent banks and hence part of their resources are transfers from the latter. Further, these banks often raise resources through inter-bank loans and instruments like certificates of deposit that are not subjected to CRR and SLR regulations.

${ }^{7}$ Given the social objectives associated with nationalization of banks in 1969 , it is not surprising that the even as late as 2003-04 over 60 percent of the branches of the state-owned banks are in non-urban areas, compared with about 45 percent for the domestic private banks. It is also not surprising that the foreign banks have branches only in urban areas. However, it should be noticed that there was a 5 percentage point decline in the non-urban share of an average state-owned bank's branching network. This one more indication that state-owned banks were making an attempt to become cost efficient and focusing more on profitability as opposed to social banking. 
${ }^{8}$ All these foreign banks were listed in the stock exchanges of their countries of origin, and sometimes
cross-listed in global stock exchanges like NYSE. However, from the point of view of empirical analysis,
both non-listed status of all foreign banks at Indian stock exchanges and listed status of all these banks at
overseas exchanges are equivalent. Since there is no variation across the foreign banks in our sample on
either count, it would not explain inter-bank variation in the credit-to-deposit ratio.

${ }^{9}$ To recapitulate, a bank that does not meet its priority sector exposure obligation is required to invest the amount of "default" in government securities that yield rates of return that are below the market rate.

${ }^{10}$ Note that in the pooled regression model for all domestic banks, we do not control for state ownership using a dummy variable. This is on account of the high degree of collinearity between ownership and characteristics like size. 